\title{
Far-field tilting of Laurentia during the Ordovician and constraints on the evolution of a slab under an ancient continent
}

\author{
Bernard Coakley! \\ Department of Geology and Geophysics, University of Wisconsin, Madison
}

\section{Michael Gurnis}

Seismological Laboratory, California Institute of Technology, Pasadena

\begin{abstract}
During a brief period of 10 to 15 million years in the Middle-Ordovician, the Michigan Basin departed from its bull's-eye subsidence pattern and tilted toward the east, opening to the Appalachian basin. This tilting is observed in maps of tectonic subsidence estimated for the Black River and Trenton Formations and extends over $300 \mathrm{~km}$ across the Michigan Basin and into eastern Wisconsin. Contours of constant tectonic subsidence rate are approximately parallel to the inferred position of the Laurentian-Iapetus convergent margin. The distance between the inferred position of the subduction zone to the limit of tilting is approximately $1000 \mathrm{~km}$. Three alternative models for the tilting are tested, two relying on the rigidity of the continental lithosphere and a third on the viscous flow generated by a subducted slab. In the first elastic model we assume the edge of the elastic plate is simply loaded from above (by a fold and thrust sheet, volcanic pile, etc.). This model, however, cannot simultaneously satisfy the space of tectonic subsidence and subsidence rate, even for lithospheres which have a rigidity of $10^{28}$ $\mathrm{Nm}$. In the second elastic model, the Laurentian continental margin descends into a trench of an eastward dipping slab, that is, a slab descending under the Iapetus ocean. This process cannot generate any significant far field displacements, even for extremely rigid plates, and must be rejected. For the third model we use finite element solutions of a negatively buoyant slab in a viscous medium with a faulted lithosphere. Such slabs can easily generate not only realistic trenches on the under thrusting plate but also significantly tilt the lithosphere as much as 1000 $\mathrm{km}$ from the plate margin. The magnitude and distribution of far-field displacements depend on the age, length, and dip angle of the slab. In contrast to the elastic models, penetration of a westdipping slab beneath the continent can reproduce both the extent, magnitude, and rate of tectonic subsidence observed in the Trenton and Black River Formations. The observed data are best fit by an old slab (140 Ma), which initially descended at a moderate dip $\left(20^{\circ}-30^{\circ}\right)$ for $10-15 \mathrm{~m} . \mathrm{y}$., which then steepened as the slab penetrated deeper into the mantle. At the position of the previous Ordovician plate margin, there are narrow, block faulted basins which underwent rapid subsidence $\sim 10$ m.y. before the Michigan Basin tilted toward the east. We propose that these earlier subsidence events were caused by the initial descent of the slab under the preexisting CambroOrdovician passive margin. The time lag of $\sim 10 \mathrm{~m}$.y. may be due to the time it takes the slab to penetrate the upper mantle. This result is important for understanding the time evolution of mantle convection and mechanisms for the initiation of subduction.
\end{abstract}

\section{Introduction}

Stratigraphic evidence [Keith, 1989; Walker et al., 1983] and forward basin models [Quinlan and Beaumont, 1984] suggest that the Michigan Basin was intermittently linked to the Appalachian foredeep, which was initiated in response to the Taconic orogeny in the Early Middle Ordovician [Rodgers, 1971]. The Ordovician section of the Michigan Basin (Figure 1) brackets the time of Taconic deformation [Bradley and Kusky, 1986] and provides a record of spatially variable tectonic subsidence over this interval [Coakley et al., 1994].

\footnotetext{
${ }^{1}$ Now at Lamont-Doherty Earth Observatory, Palisades, New York.
}

Copyright 1995 by the American Geophysical Union.

Paper number 94JB02916.

0148-0227/95/94JB-02916\$0.500
Previous analyses of the stratigraphy of the Michigan Basin have recognized the irregular history of basement subsidence and attributed it to episodic thermal events [Nunn, 1986], an unspecified linkage to the phases of the Appalachian orogeny [Ahern and Dikeou, 1989; Sleep et al., 1980] or to weakening of the lower crust during intervals of thrust activity in the Appalachian thrust belt [Howell and van der Pluijm, 1990]. Each mechanism has the potential to explain the observed episodic subsidence. None has been quantitatively tested.

It has long been observed in isopach data [Cohee, 1948; Cook and Bally, 1975] that a distinctive change in the style of subsidence occurred during the Middle Ordovician, beginning with the deposition of the Black River Formation and continuing through the accumulation of the Trenton Formation. Isopachs of these formations show a distinctive opening of the basin toward the Appalachian basin in the east, contrasting with the earlier and later classic basin centered ("bull's-eye") subsidence patterns. The tilting extends at least 
a

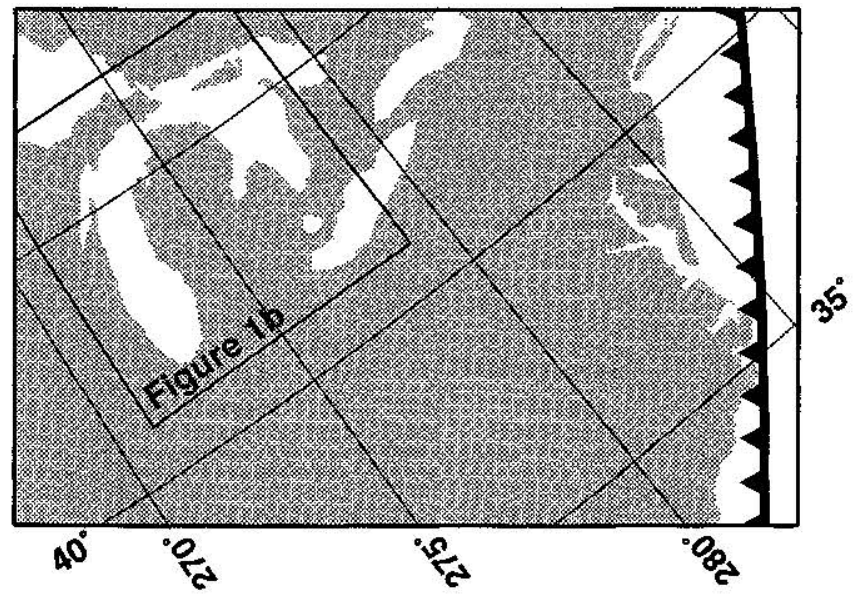

b

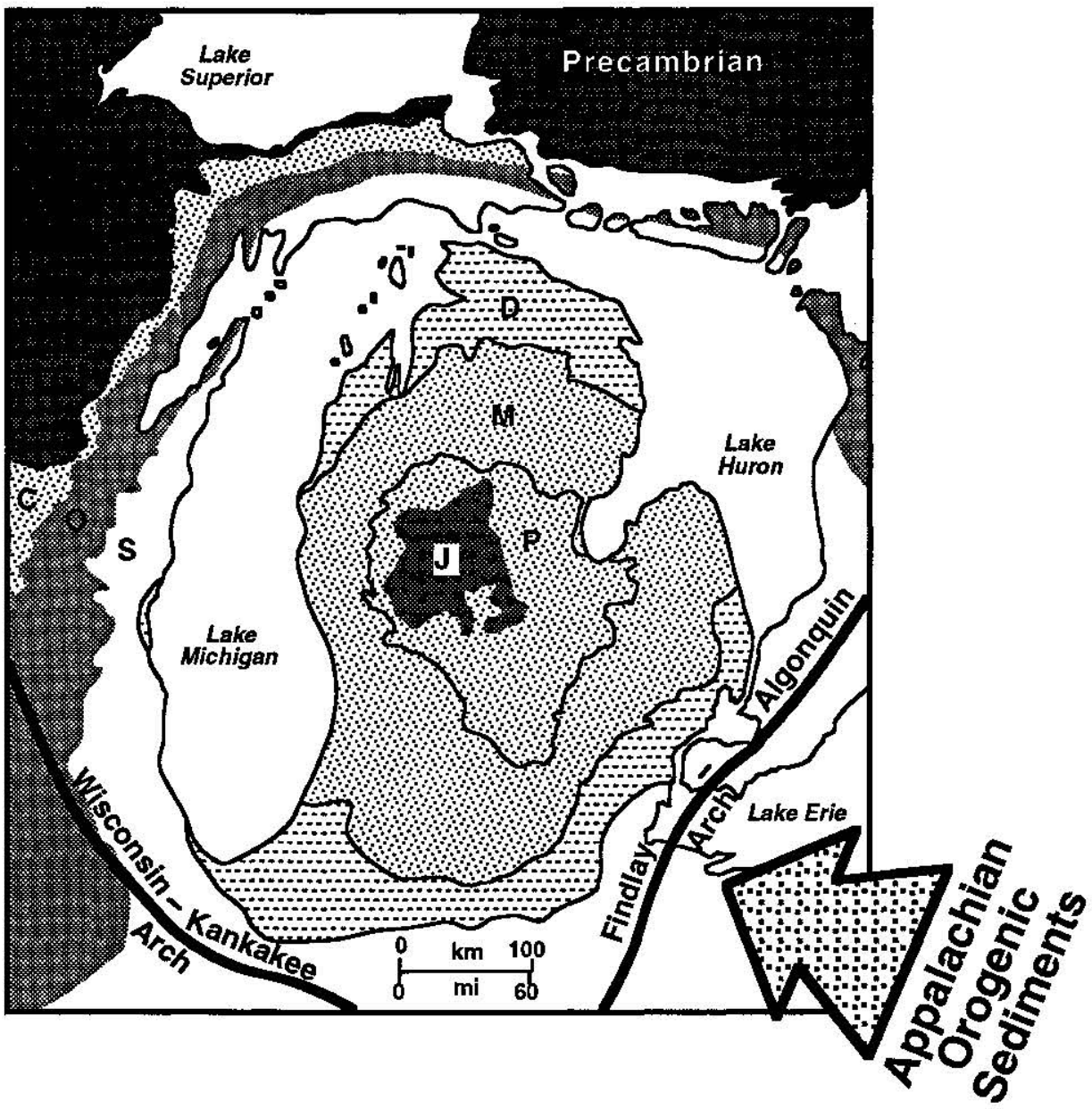

Figure 1. (a) Map showing the location of the Michigan Basin sediments in relation to the Ordovician margin of Laurentia. (b) Generalized geologic map of the Michigan Basin; shown in gray is the outcrop area of Ordovician sediments.

$1000 \mathrm{~km}$ from the inferred plate margin to eastern Wisconsin. The extent of this deformation is difficult to explain with models of supracrustal loading imposed on an elastic lithosphere, requiring extreme lithospheric rigidities compared to recent estimates of continental strength [Grotzinger and Royden, 1990; Karner et al., 1983], which range between $10^{22}$ and $10^{25} \mathrm{Nm}$ (equivalent elastic thicknesses between 5 and $125 \mathrm{~km}$ ). For this reason we prefer a model of subcrustal loading, due to penetration of a slab of oceanic lithosphere following a change in subduction polarity [McKerrow et al., 1991], to explain the regional eastward tilting of eastern Laurentia. This quantitative model reproduces the extent, magnitude, and rate of tilting estimated from stratigraphy.

There has been renewed attention given to the issue of large scale tilting of continents following Mitrovica et al.'s [1989] demonstration of far field tilting of western North America during the Cretaceous. Tilting has been considered by Gallagher et al. [1994] and Russell and Gumis [1994] for the Cretaceous of eastern Australia, by Peper [1994] for the Canadian Rocky foreland in the Cretaceous, and by Janssen et al. [1993] for the Iberian margin during the Pliocene. 


\section{Geology of Eastern Laurentia During the Ordovician}

During the Cambrian and Early Ordovician, the Sauk sequence [Sloss, 1963], Laurentia was an equatorial continent surrounded by passive margins which accumulated mature clastic and carbonate rocks. To the east, in current coordinates, was the Iapetus ocean, a broad, old oceanic basin [Van der Voo, 1993], similar to the present-day Atlantic Ocean. The end of Sauk deposition is marked by the development of the Knox unconformity, an interregional surface showing extensive karstification, indicating a fundamental change in the circumstances of sediment accumulation. Jacobi [1981] has attributed the uplift and exposure of the carbonate platform rocks of the Knox group to the advance of a flexural bulge caused by supracrustal loading of the growing Taconic thrust wedge. This interpretation is compatible with the currently held popular view of east dipping subduction concurrent with the Taconic orogeny [Bird and Dewey, 1970], supported by the vergence of ophiolites in Newfoundland. The age of thrusting in western Newfoundland is Early Ordovician, estimated to be Llanvirnian, near Hare Bay, and Llandeilian, around Bay of Islands and Humber Arm [McKerrow, 1988].

More recent reconstructions, based on paleomagnetic data, paleoclimatology, biogeography and plate kinematics [McKerrow et al., 1991; Scotese and McKerrow, 1991] supports a reversal of subduction polarity, beginning in the early Caradocian. The penetration of a cold, subducted slab beneath a continent should depress the overlying continental lithosphere downward due to the viscous flow driven by the slab itself [Gurnis, 1992; Mitrovica et al., 1989]. The tilting observed in Middle Ordovician carbonates of eastern Laurentia provides a means to test the compatibility of the inferred subduction polarity with its predicted dynamic effect.

The influence of the Taconic orogeny to the west can be recognized through time stratigraphic correlation and examination of the lithostratigraphy. The earliest known easterly derived sediments in the Appalachian basin are turbidites, dated as Whiterockian (Figure 2) [Shanmugam and Walker, 1978], indicating the development of topography on what had been a passive margin. Beneath these turbidites is a thin transgressive carbonate sequence, which overlies the Knox unconformity [Jacobi, 1981; Rodgers, 1971]. Mussman and Read [1986] and Knight et al. [1991] have expanded on this earlier work, utilizing more detailed stratigraphy and sedimentological observations, providing a regional basis for understanding the Sauk/Tippecanoe sequence boundary in Eastern North America. In the Michigan Basin [Catacosinos et al., 1990] the Shakopee Formation, which underlies the Knox

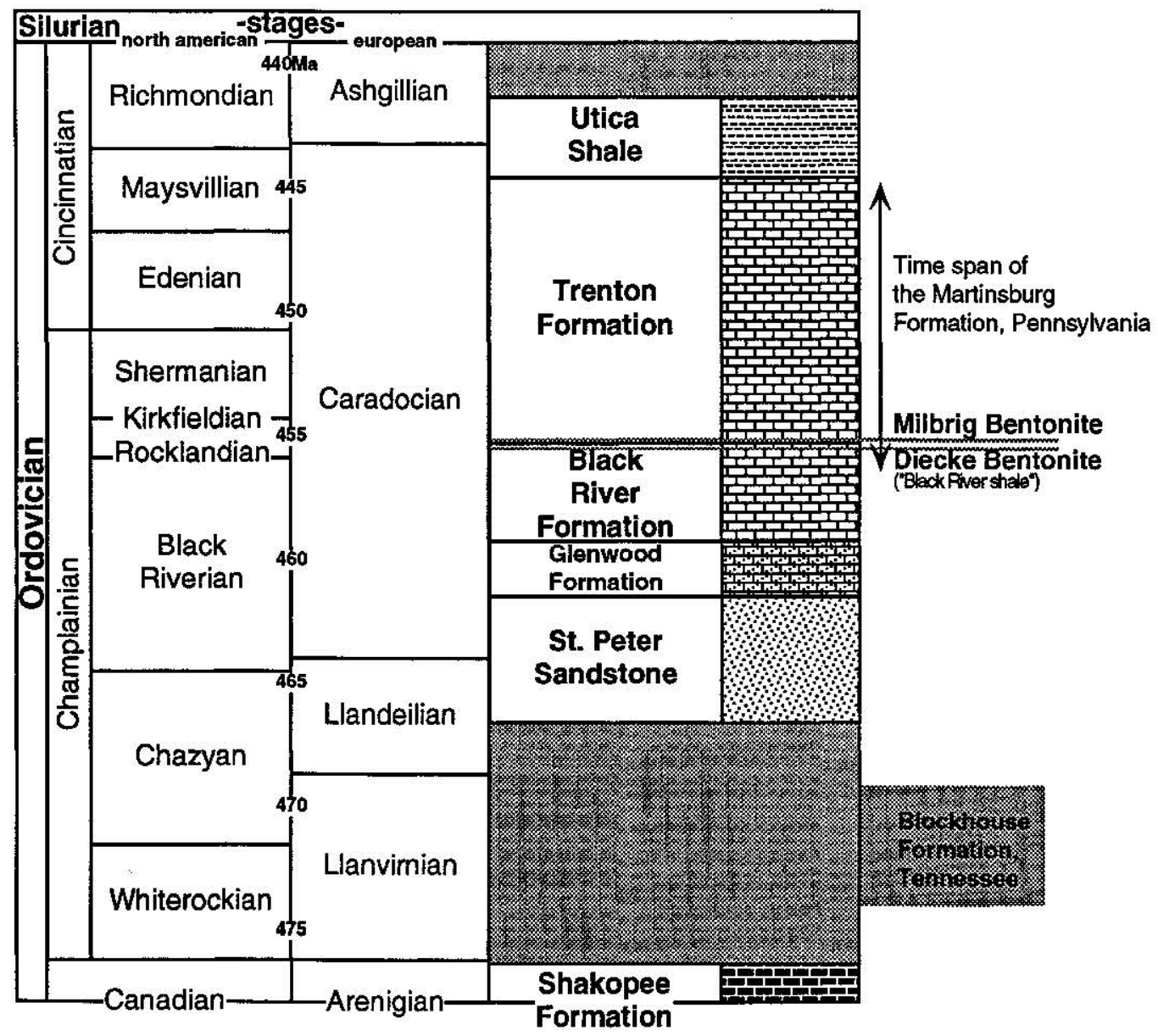

Figure 2. Stratigraphic column for the Ordovician with absolute age constraints indicated. Hiatuses are indicated by a gray shading. Ages of North American stage boundaries are estimated from the composite standard section for conodonts developed by Sweet $[1984,1988]$. Ages for European stages come from Harland et al. [1990]. Carbonate lithologies are indicated by the blocky patterns, clastics by stippling or linear patterns. Sauk/Tippecanoe sequence boundary, described in the text, falls between the St. Peter Sandstone and the Shakopee formation. 
unconformity (Figure 2), was uplifted, subaerially exposed and karsted in the east-central Michigan Basin [Nadon and Smith, 1992].

Overlying the Knox unconformity in the Michigan Basin and therefore postdating the onset of the Taconic orogeny are the St. Peter sandstone and the Glenwood, Black River, and Trenton Formations (Figure 2). Examination of the spatial distribution of tectonic subsidence over this interval shows a change from basin-centered subsidence prior to Black River deposition (Figure 4a) eastward tilting during deposition of the Trenton and Black River Formations (Figure 4b) and a return to basin-centered subsidence during the Silurian [Coakley et al., 1994; Howell and van der Pluijm, 1990]. The extent of this tilting is difficult to understand in the context of a thermally driven basin forming mechanism (note the weak long-term subsidence seen in the tectonic subsidence curves shown in Figure 3) or as a regional response of a strong lithosphere to supracrustal loading. To understand the influence of the Taconic orogeny on the Michigan Basin we quantitatively compare tectonic subsidence rates, magnitudes, and distributions predicted for different mechanisms of supracrustal and subcrustal loading to the tectonic subsidence observed in the sediments of the Trenton and Black River Formations.

\section{Estimating Tectonic Subsidence}

Isostatic principles require that the mass of basin fill displace the viscous mantle. Because typical sediment densities are less than estimated mantle density, a driving mechanism is necessary to explain any permanent subsidence. The driving mechanism can be viewed as making subaqueous

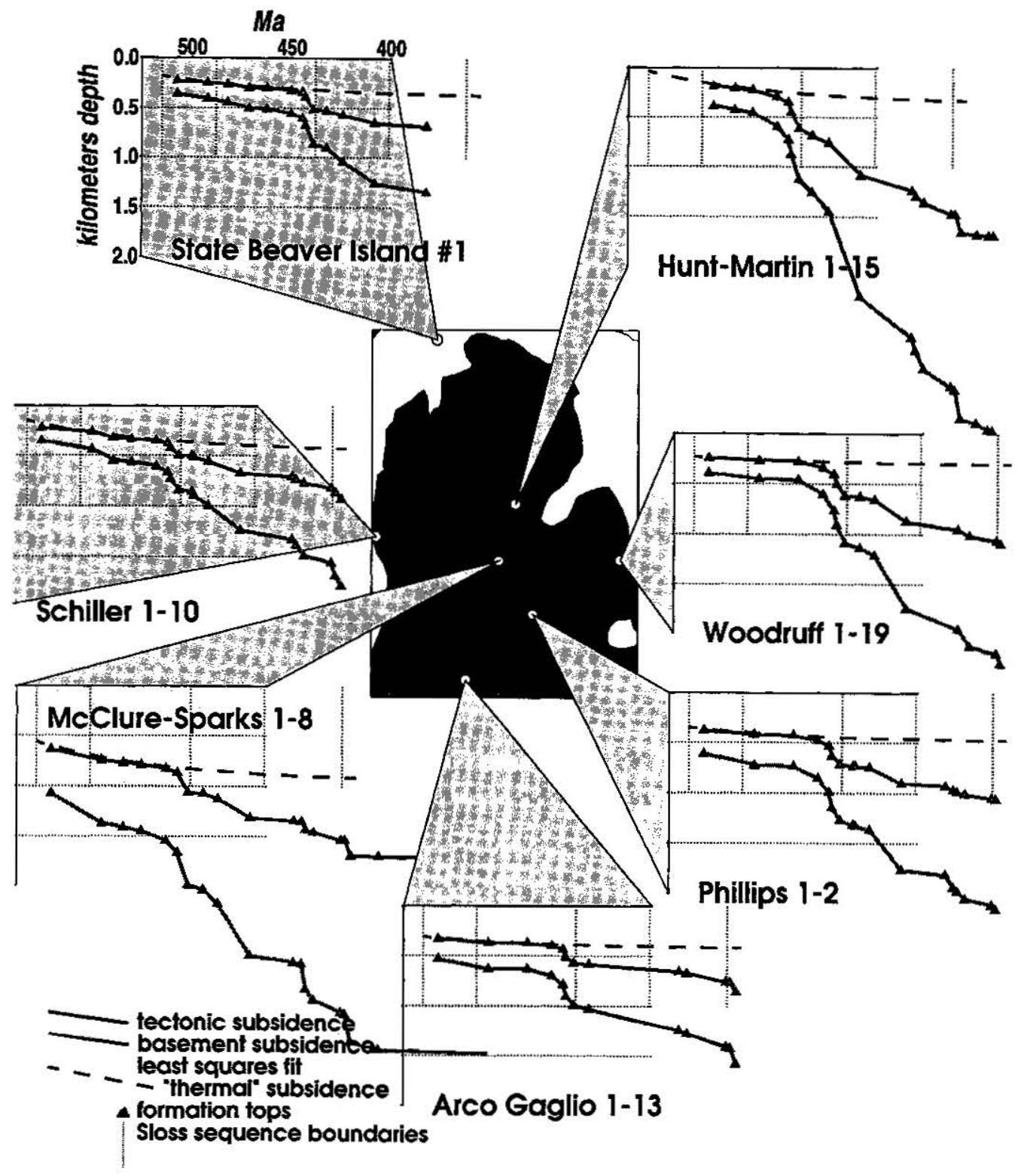

Figure 3. Tectonic and basement subsidence curves for selected deep wells from the Michigan Basin. All plots share the same vertical and horizontal scale. Vertical dotted lines indicate the boundaries of Sloss's sequences [Sloss, 1963]. Dashed lines indicate "thermal" subsidence curves estimated fitting theoretical subsidence curves [McKenzie, 1978] to formations predating the onset of deposition of the Black River Formation. Steps seen in the tectonic subsidence curves are manifest in the same formations throughout the basin. The step seen at approximately $450 \mathrm{Ma}$ is due to the tilting shown in Figure 4. 
space available for sedimentation. Conditioned by certain assumptions, it is possible to use a sedimentary column to estimate the magnitude of this tectonic subsidence at a point over time. Backstripping assumes that sediment compaction is a function of burial depth, that isostatic compensation is local, and that sedimentation keeps the basin full to sea level at all times [Steckler and Watts, 1978]. Using these simplifying assumptions we successively remove each layer, decompact the underlying section, correct for the loading effect of the removed sediment, track the depth to basement and estimate the magnitude of tectonic subsidence. This is a minimum estimate of the amount of subaqueous space made available for sediments by the basin-forming mechanism(s) active during that time interval.

Estimated tectonic subsidence curves are often approximately exponential in form, similar to subsidence curves observed at mid-ocean ridges [Parsons and Sclater, 1977]. Empirical support for thermal mechanisms of basin subsidence are based on the form of tectonic subsidence curves. The significance of a thermal mechanism is well established for passive margins where thinned continental crust is continuous with cooling oceanic lithosphere [Watts, 1982]. The observation of exponential subsidence is compatible with the plate tectonic context. Intracratonic basins are poorly understood. Tectonic subsidence curves have been used to argue that intracratonic basins form over thinned lithosphere and that the decay of the subsidence rate reflects cooling of the underlying, uplifted asthenosphere [Sleep and Snell, 1976]. If true, deviations from exponential trends are due to violation of the assumptions underlying the thermal subsidence and backstripping analysis. These deviations have been interpreted in different settings as being caused by changes in sea level [Thorne and Watts, 1984], variations in the magnitude of in-plane stress [Cloetingh et al., 1990; Cloetingh et al., 1985; Karner, 1986], metamorphism of the upper mantle [Hamdani et al., 1991], repetitive heating of the lithosphere [Sleep et al., 1980], or enhanced cooling of the upper mantle due to fluid advection [Nunn, 1994]. Deviations can also be due to incorrect ages assigned to formation tops, section lost to erosion, diachronous formation tops, aggradation of the section above sea level, lateral support of the sediment load due to lithospheric flexure, inaccurate decompaction, or the introduction of a perturbing mass at depth.

Figure 3 shows the evolution of depth to basement, tectonic subsidence, and a thermal subsidence curve fit exclusively to pre-Black River Formations for seven deep wells in the Michigan Basin. Striking is the weakness of the long-term subsidence and the irregularity of the tectonic subsidence curve [Bond and Kominz, 1991]. Stretching factors [McKenzie, 1978] determined from these and other wells are all within the range of 1.05-1.40. This pattern is observed in all of the deep wells in our database. Particularly interesting is the apparent increase in subsidence rate evident during Black River and Trenton deposition. If subsidence "events" seen in individual backstripped wells are meaningful (Figure 4), they should be coherent over the basin, that is, groups of wells should present a pattern of subsidence that we may relate to causes. We have backstripped the formation tops from 260 wells, using the decompaction parameters of Sclater and Christie [1980], gridded and contoured the sediment thickness, decompacted sediment thickness and tectonic subsidence to reveal these patterns in map view and move beyond local stratigraphic noise, which may introduce spurious subsidence "events" in tectonic subsidence curves derived from a single well. Figure $4 \mathrm{~b}$ shows the isopachs and the tectonic subsidence rates for the Black River and Trenton Formations. Black River and Trenton Formation decompacted isopach and tectonic subsidence rate maps show that the basin tilted toward the east. Underlying (Figure 4a) and overlying formations show a contrasting pattern of basin-centered subsidence [Coakley et al., 1994] demonstrating a distinctive change in the spatial distribution of tectonic subsidence during the Black River-Trenton interval.

\section{Absolute Age Constraints on the Tilting}

The mechanism we propose to explain the Middle to Late Ordovician tilting of eastern Laurentia can be validated by comparison to the extent, magnitude, and rate of tectonic subsidence over the time interval represented by the preserved thickness of Black River and Trenton sediments. To utilize the tectonic subsidence rate as a constraint on the dynamic models presented below, we need to delimit the absolute time interval over which these units were deposited. Absolute ages on bentonite layers and graphic correlation techniques applied to conodont controlled measured sections provide the primary constraints. Sweet [1984, 1988] used graphic correlation techniques to assign numerical ages to paleontologically defined data and stage boundaries (Figure 2) from the Middle and Upper Ordovician of North America. Seventy measured sections, which shared common paleontologically or physically defined datum horizons, were used to construct a complete composite stratigraphic section. The resultant composite section, when calibrated in absolute time, provides a standard that can be used to assign ages to the various datum horizons used to construct it. The composite standard section is calibrated in time by the length of the post-Whiterockian Ordovician (Figure 2).

The composite standard section [Sweet, 1984, 1988] was used to define the age of the North American stages and delimit the time interval represented by Black River and Trenton sediments (Figure 2). Ages presented on Figure 2 were calculated assuming that post-Whiterockian time spanned 30 m.y. and that the basal Silurian is $439 \mathrm{Ma}$ [Harland et al., 1990]. European stages were added to Figure 2 using the ages of Harland et al. [1990].

Because the tilting is best defined in sediments of the Black River and Trenton we are primarily concerned with bounding the time represented by this accumulation. Basal Black River of the type locality is assigned the age of $459 \mathrm{Ma}$ [Sweet, 1988]. The Black River-Trenton contact is well dated due to the proximity of the Diecke bentonite, which is dated variously as $453.7 \pm 1.8 \mathrm{Ma}$ [Tucker et al., 1990] and $457.1 \pm 1.0 \mathrm{Ma}$ [Samson et al., 1989]. We take the age of the Diecke bentonite to be $455 \mathrm{Ma}$, so the interval of Black River accumulation is approximately $4 \mathrm{~m}$.y. The upper contact of the Trenton Formation is believed to project into the Maysvillian [Sweet, 1988], so the age is assigned to be $444 \mathrm{Ma}$, making the total time span of Trenton and Black River accumulation 15 m.y.

The period of Black River and Trenton accumulation is within the Caradocian European stage. The correlation of the Diecke bentonite to the "Big Bentonite" [Huff et al., 1992] of Baltoscandia provides a tie point. The apparent volatility of the length of the Caradocian on calibrated timescales [Tucker et al., 1990] suggests that a range of ages might provide a more appropriate means to validate the model. Recent 
a
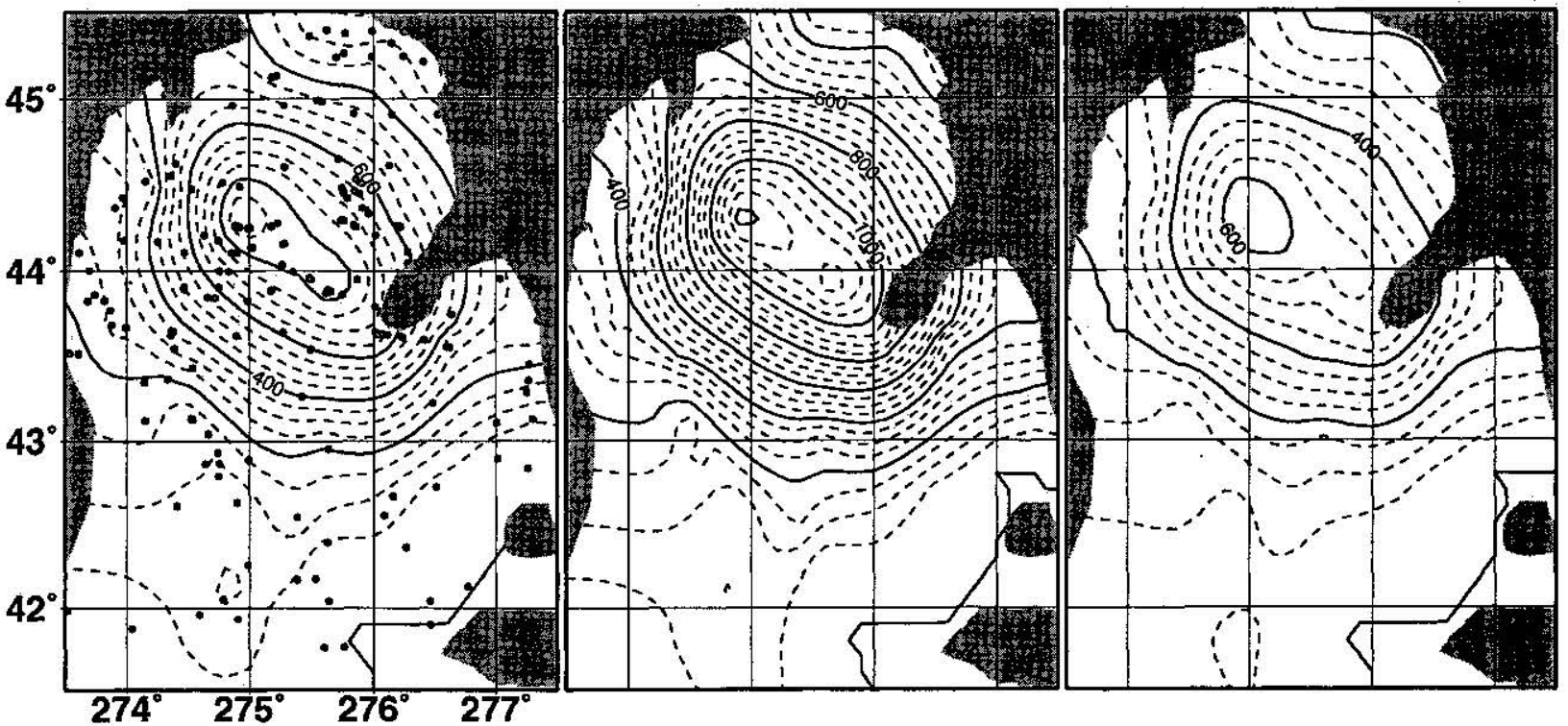

$\mathbf{b}$

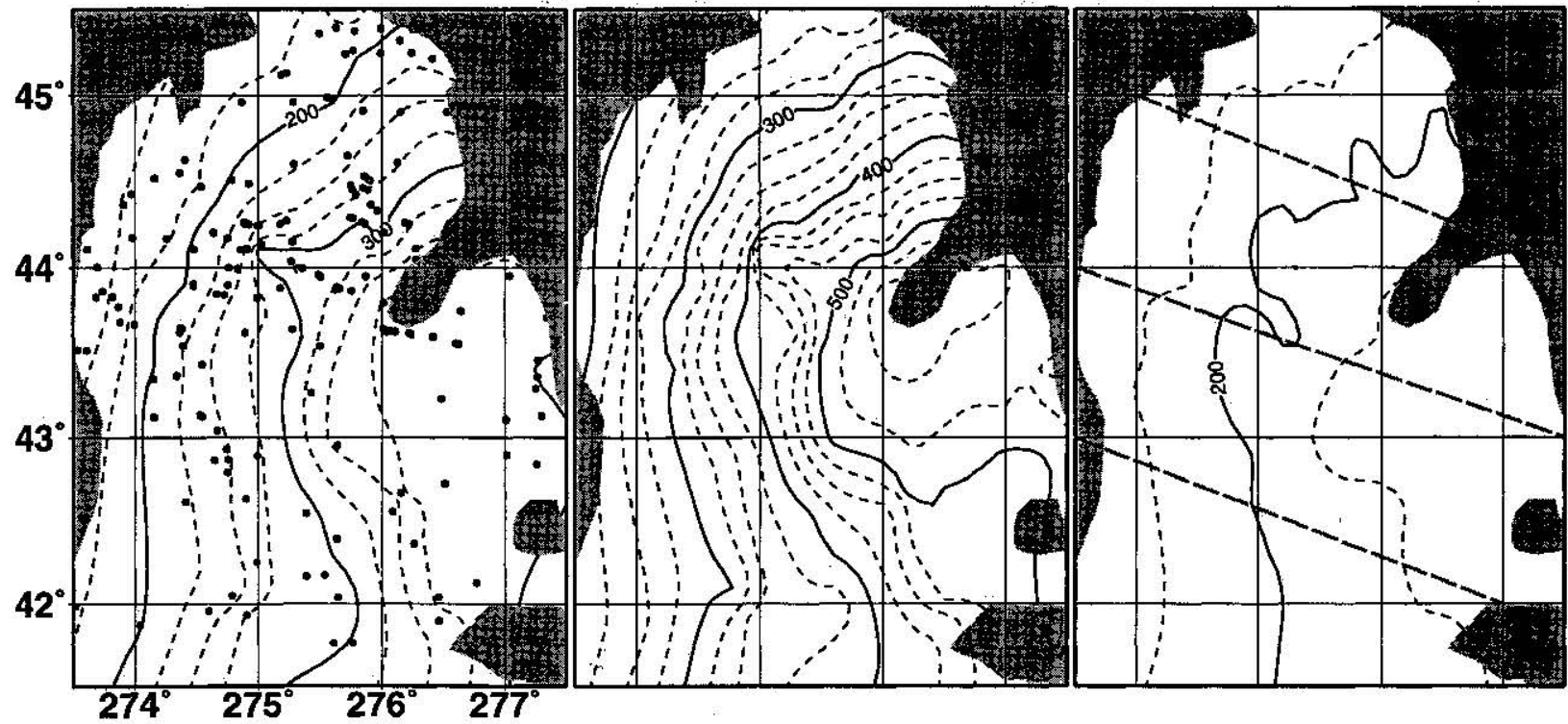

Figure 4. Isopach, decompacted isopach, and tectonic subsidence rate maps for Middle Ordovician sediments in the Michigan Basin. Contour interval on the isopach maps is $50 \mathrm{~m}$ in Figure $4 \mathrm{a}$ and $25 \mathrm{~m}$ in Figure $4 \mathrm{~b}$. Contour interval on the tectonic subsidence rate is $1 \mathrm{~m} / \mathrm{m}$.y. Gray dots on the isopach map indicate well penetration. (a) Basin-centered subsidence manifested in the Shakopee, St. Peter, and Glenwood Formations. (b) Tilting evident in the Black River and Trenton Formations. Sample profiles used for model validation are shown on Figure $4 b$.

geochronological work [Tucker et al., 1990] suggests that the post-Whiterockian Ordovician may span about 20 m.y., limiting the time span of Black River-Trenton accumulation to about $10 \mathrm{~m} . \mathrm{y}$. and providing an upper bound for subsidence rates used to validate the models.

To define minimum and maximum bounds on the subsidence rate across the Michigan Basin, we used three profiles which are approximately perpendicular to lines of constant tectonic subsidence (Figure $3 b$ ). With these profiles we found the maximum and minimum subsidence of the combined Black River and Trenton Formations at approximately equal distances from the inferred Ordovician active margin. These two profiles were normalized by the minimum time span $(10$ m.y.) and the maximum (15 m.y.) time span of the combined
Black River and Trenton Formations to define bounds on the maximum and minimum subsidence rates. Models which fell between bounds on both total subsidence and subsidence rate were judged acceptable.

\section{Physical Models for the Development of Platform Tilting}

Supracrustal and subcrustal loads can tilt continental platforms. In the case of supracrustal loads the rigidity of continental lithosphere horizontally distributes the influence of the vertical load. In the case of the subcrustal loads, viscous forces in the mantle, in particular those associated 
with negatively buoyant subducting slabs, can extend over broad regions; the deformation is dependent on the rate and extent of slab penetration into the mantle. Because the topographic expression of subcrustal loads is also influenced by lithospheric strength, there is no clear demarcation between the two types of loading. Three alternative models for the generation of platform tilting are explored (Figure 5): supracrustal loảds on an elastic lithosphere, descent of continental lithosphere into a trench, and the descent of a subducted slab under a continent and through the upper mantle following the initiation of subduction. The purpose of this analysis is to demonstrate, first, that both models depending on the elastic strength of the lithosphere are incapable of reproducing the rate and extent of observed deformation and, second, that the initiation of subduction and descent of a slab through the upper mantle provides a plausible explanation for the Middle Ordovician tilting of North America.

Since the results and methods of Zhong and Gurnis [1994] are used for the second two models discussed below, we will review those results here. We use Zhong and Gurnis's [1994] two-dimensional finite element analysis of viscous flow in which the high viscosity lithosphere is cut by a fault (Figure 6). The dominant topographic expression associated with a subducted slab is an oceanic trench, but flow of a viscous fluid alone generated by a subducted slab cannot generate trenches.

\section{Contrasting Tilt Models}

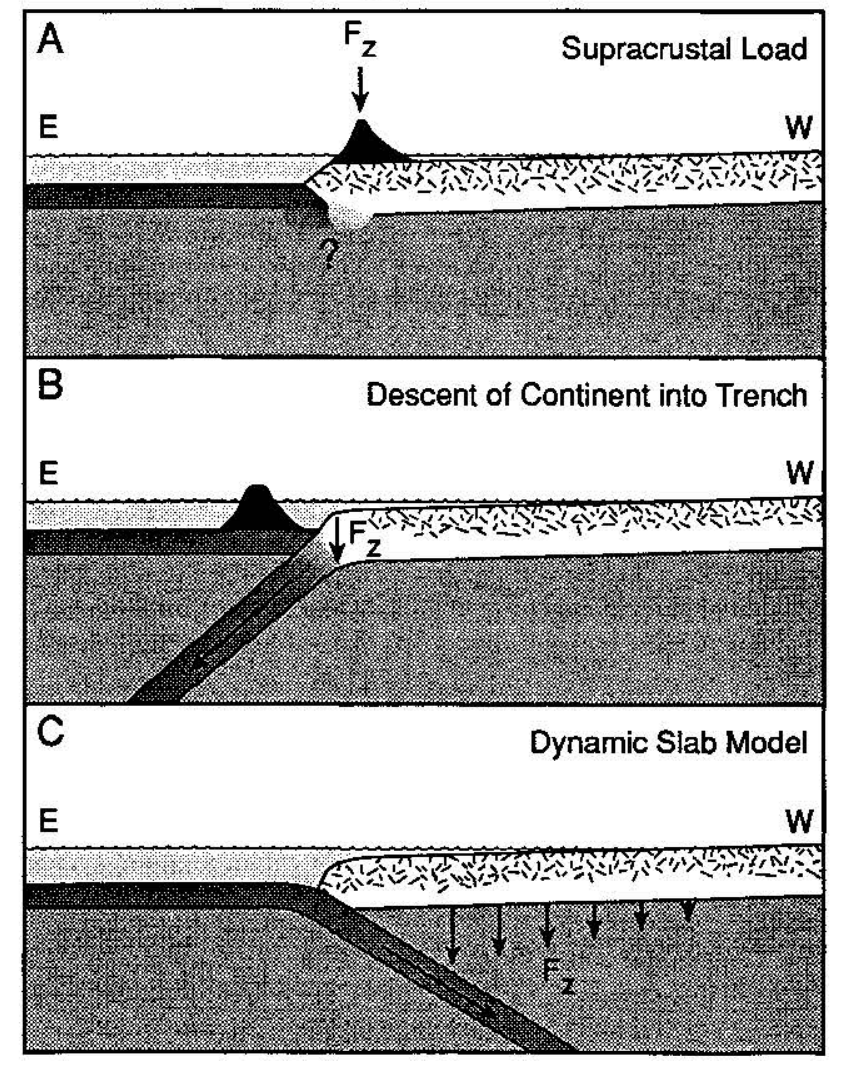

Figure 5. Cartoon illustrating the three tilting mechanisms considered in the text. (a) The supracrustal load model and (b) the descent of the continental plate into a trench model (depend on the elastic strength of the continent, while (c) the dynamic slab model depends on the geometry of the westward dipping slab.
If the flow is at least partly decoupled along an inclined plane between subducting and overriding plates then trenches form; the modeled trenches are consistent with all significant observed features of trenches, including trench width, gravity, geoid, and dependence of trench depth on plate age, slab dip angle, and fault dip angle [Zhong and Gurnis, 1992, 1994].

Slow creeping flow is driven by the negative buoyancy of a cold slab (Figure 6); realistic vertical variations in viscosity, including a low-viscosity zone, are incorporated into the model (Table 1). Since we are interested in the stress field associated with a given slab configuration (characterized by age of lithosphere subducting, length of slab, and angle of subduction) we only compute the instantaneous Stokes flow. Dynamic topography is computed directly on the top surface of the fluid from the vertical, normal viscous stress [e.g., McKenzie, 1978; Richards and Hager, 1984]. The fault is characterized by continuity of both the velocity and stress normal to the fault, and discontinuous shear velocity and stress across the fault. Zhong and Gurnis [1994] prefer a resisting shear stress of $15 \mathrm{MPa}$ to $30 \mathrm{MPa}$, but we have decided to use a no-slip condition along the fault (no resisting shear stress) for the following reason. The resisting shear strength has only a small influence on the topography of the overriding plate but makes the trench shallower. Consequently, by assuming no shear stress, our trench is deeper than observed. In the second model simulating the motion of a continent into a trench, the effect is to increase the influence of bending the continent downward as it approaches the trench. Since this model is ultimately rejected based upon the negligible far-field influence of the end load, the neglect of a fault resisting stress is a conservative simplifying assumption.

Predictions of continental tilting in the back arc region are modified by the presence of a fault. Since previous studies of the influence of a slab on topography of the overriding plate have used purely viscous rheologies with constant viscosity [Mitrovica et al., 1989] or spatially variable viscosity [Gurnis, 1992, 1993], the current study using a faulted lithosphere in a medium with depth dependent viscosity is far more realistic. Output from all models is shown as both total tectonic subsidence and subsidence rate, since the element of time provides further constraints on the driving forces of Ordovician tilting. The principle uncertainties in our comparison of models with the observed tilting are the time interval over which the Black River and Trenton Formations were deposited (discussed earlier) and the original distance between the platform sediments and the trench at the Laurentian and Iapetian active margin. These uncertainties limit the precision of the various parameters derived from modeling the influence of subcrustal loads but do not contradict the mechanism proposed here.

\section{Supracrustal Load}

We explore the tilting which results from loading a twodimensional thin elastic plate with a free end subject to a vertical restoring force. Hetenyi [1947] has derived solutions for a point load on an elastic beam; since we have a system with a uniform elastic rheology, a spatially distributed load can be constructed from the superposition of point loads. Given a constant density infill, the amplitude and wavelength of the deformation are independent; the wavelength is controlled only by the strength of the elastic lithosphere and the amplitude of the deformation is controlled by the 


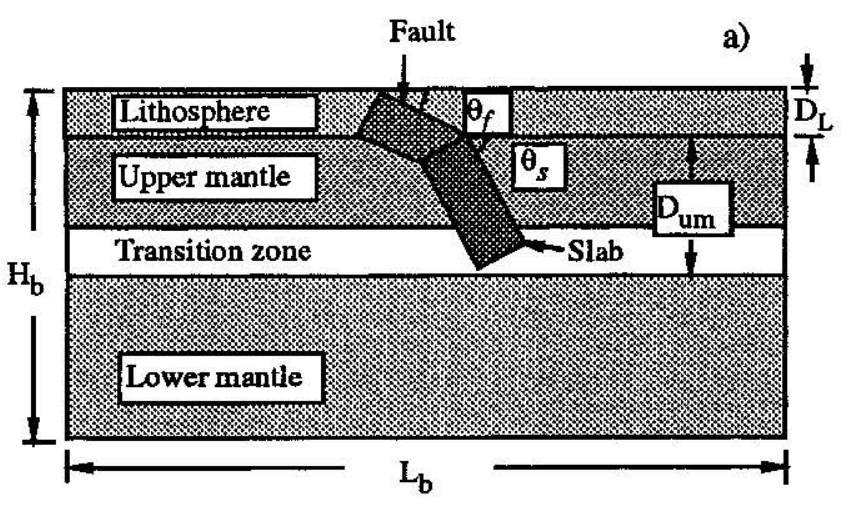

b)

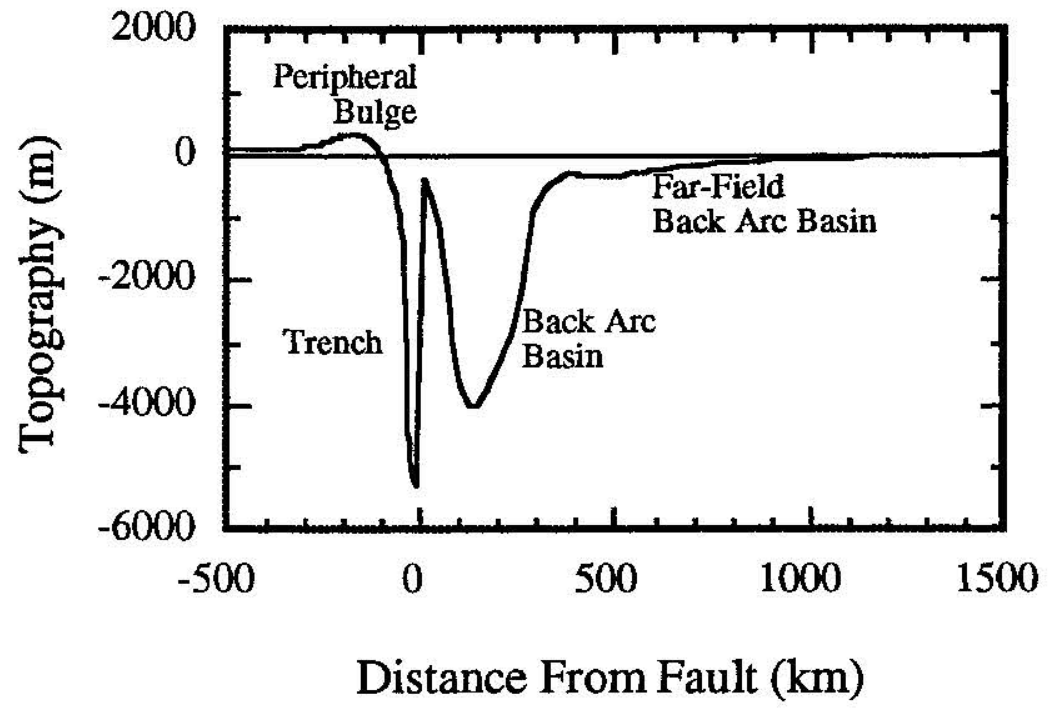

Figure 6.(a) Geometry of the finite element domain used to calculate viscous flow and dynamic topography in the vicinity of a slab. (b) Dynamic topography over a slab with an age of $160 \mathrm{Ma}$ embedded in a viscous mantle. The lithosphere is cut by a $30^{\circ}$ dipping fault with a $20 \mathrm{MPa}$ resisting shear stress.

magnitude of the load. Since the elastic model is not time dependent, subsidence rate at any point is proportional to the loading rate. We examine loads of a uniform thickness (with a density of $2700 \mathrm{~kg} \mathrm{~m}^{-3}$ ) applied near the end of the plate, over a defined time period and constant lithospheric flexural rigidity. Comparison of the load and lithospheric strength necessary to reproduce the observed data permits an evaluation of the utility of supracrustal loading on an elastic lithosphere to explain the observations.

Load A consists of a 3-km-thick pile distributed between 100 and $200 \mathrm{~km}$ of the plate edge and created in $10 \mathrm{~m} . \mathrm{y}$. Such a load could represent volcanic construction, fold and thrust sheets, a narrow clastic wedge, or some combination of all three. The load used is similar to the largest loads estimated for the Cretaceous aged Idaho-Wyoming thrust belt [Jordan, 1981]. Far-field tilts can be generated with such a scenario if the rigidity is greater than about $10^{27} \mathrm{Nm}$ (Figure $7 \mathrm{~b}$ ); however, the longwavelength displacement is about an order of magnitude too small. But more importantly, the high rigidity necessary to reproduce the wavelength of tilting is about 3 orders of magnitude larger than the range estimated from platform areas [Grotzinger and Royden, 1990; Karner et al., 1983]. If anything, the inferred dependence of rigidity on plate age at the time of loading [Grotzinger and Royden, 1990] suggests that lower values may be more appropriate for the Ordovician. The observed Black River tilting could be brought into accord with the predictions of a lower rigidity if we have overestimated the lateral extent of the tilting; if we have overestimated the trench to Michigan distance by $400 \mathrm{~km}$

Table 1. Parameters for Finite Element Models of Subducted Slabs

\begin{tabular}{|c|c|}
\hline Parameters & Value \\
\hline \multicolumn{2}{|l|}{ Viscosity } \\
\hline Lithosphere & $2 \times 10^{22}$ \\
\hline Upper mantle & $3 \times 10^{20}$ \\
\hline Transition Zone & $6 \times 10^{21}$ \\
\hline Lower Mantle & $3 \times 10^{22}$ \\
\hline Temperature difference of $80 \mathrm{Ma}$ lithosphere, $\mathrm{K}$ & 650 \\
\hline Reference Density of Mantle, $\mathrm{kg} \mathrm{m}^{-3}$ & 3300 \\
\hline Coefficient of Thermal Expansion, $\mathrm{K}^{-1}$ & $2 \times 10^{-5}$ \\
\hline Angle of fault, degrees & 30 \\
\hline Depth of fault, $\mathrm{km}$ & 100 \\
\hline Resisting shear stress on fault, $\mathrm{MPa}$ & 0 \\
\hline Box width, km & 4500 \\
\hline Box depth, $\mathrm{km}$ & 1500 \\
\hline
\end{tabular}



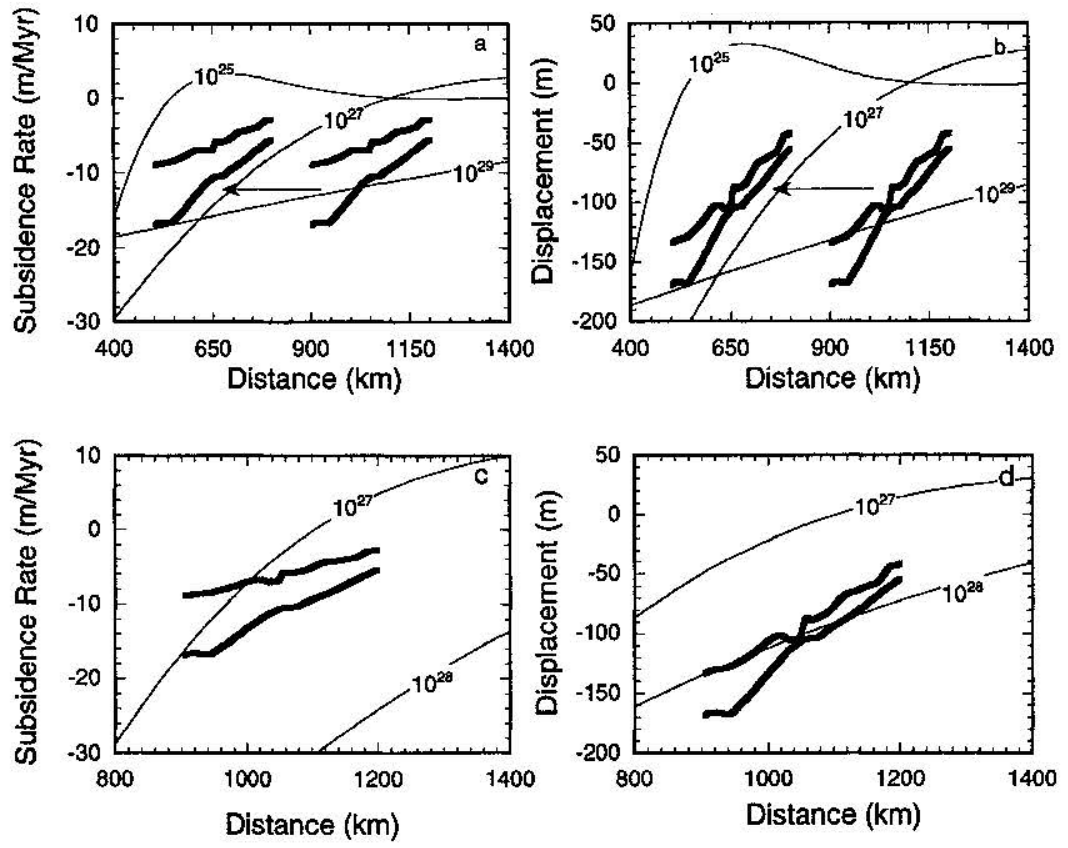

Figure 7. (a) Subsidence rate and (b) displacements for load A, defined in the text, on top of a thin elastic plate. (c) Subsidence rate and (d) displacements for load B. In Figures 7a and $7 \mathrm{~b}$ we have "moved" the Ordovician sediments $400 \mathrm{~km}$ closer toward the plate margin.

(i.e., overestimated the distance by a factor of 1.7 ; illustrated in Figures $7 \mathrm{a}$ and $7 \mathrm{~b}$ by the arrows), then displacements as large as those observed could be generated by a plate with a rigidity of $10^{26}-10^{27} \mathrm{Nm}$, about 2 orders of magnitude larger than the largest present-day estimates. The absence of significant extensional deformation west of the coastal plain argues that we have not overestimated this distance. Significant post-Taconic shortening may argue that this distance has been underestimated.

Finally, we could increase the magnitude of the distributed end load: load B extends over the entire $400 \mathrm{~km}$ end of the plate and is again $3 \mathrm{~km}$ thick, and created in $10 \mathrm{~m} . \mathrm{y}$., a factor of 4 larger than load A. Since this represents a huge mass flux, it must be considered extreme compared to known geologic processes. With load B the observed tilting and subsidence rates can be reproduced with plate rigidities between $10^{27} \mathrm{Nm}$ and $10^{28} \mathrm{Nm}$ (Figure $7 \mathrm{~b}$ ). It should be pointed out that such a large and wide load is inconsistent with the lack of clastic sediments in this pre-Taconic, pre-Queenston clastic wedge time interval. The observed tilting of the Ordovician of Michigan cannot be reproduced with either plausible supracrustal loads or lithospheric strengths. In order to obtain the observed tilts it is necessary to invoke a combination of an extremely stiff lithosphere and rapid accretion of thick, wide loads.

\section{Attempted Subduction of Laurentia}

An alternative elastic model based upon the ideas first presented by Shanmugam and Lash [1982] can be formulated (Figure 5b). For this purpose we suggest that Laurentia was attached to an east-dipping slab of oceanic lithosphere which dragged the continent into a trench, below the Iapetus ocean. This model is similar to circumstances along the northwestern margin of Australia whereby the Australian continental margin has descended into a deep oceanic trench, the Timor Trough.
To model this process, we use a combination of elastic and viscous methods: the dynamic topography (i.e., the trench topography or load) is taken from the modeling of a slab with a faulted lithosphere as discussed above. The viscous stresses for a slab with an age of 160 Ma gives rise to a trench with a depth of about $5 \mathrm{~km}$ and a width of $100 \mathrm{~km}$ (Figure 6). An old slab was used since the continental lithosphere presumably would have been attached to old oceanic lithosphere, similarly as the eastern margin of the North American today borders on Mesozoic-aged oceanic lithosphere.

Initially, the ocean-continent margin is at a distance $\Delta t V_{c}$ from the trench (Figure 8) where $V_{c}$ is the convergence velocity toward the trench. After a time, $\Delta t$, the continental margin intersects the exact boundary separating the underthrusting from the overriding plate. The dynamic topography loads a thin elastic plate; from the difference in deflection between time 0 and $\Delta t$, we find the subsidence rate of
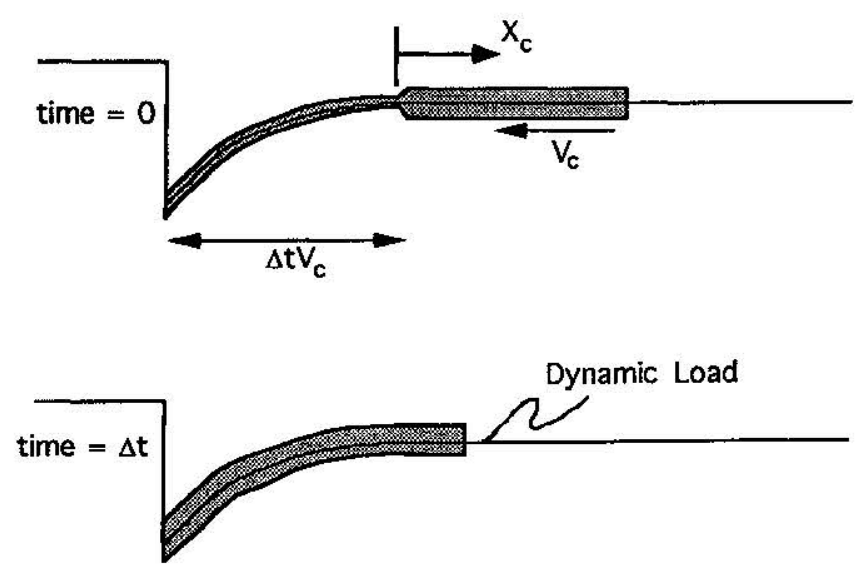

Figure 8. Schematic showing the geometry and quantities used to model the descent of a continent into a trench. 
the continent in a continent fixed coordinate system, $x_{c}$. The rigidity of the oceanic and continental plates are assumed to be the same and the free end of the plate is either at the position of the trench or the continental margin. When $x_{c}$ is large ( $1000 \mathrm{~km}$ ), the latter assumption does not significantly influence the results since $\Delta t V_{C} / x_{C}$ is small (less than $10^{-1}$ ).

For the set of plausible parameters, $\Delta t=10 \mathrm{~m} . \mathrm{y}$. and $V_{c}=5$ $\mathrm{cm} / \mathrm{yr}$, we find that neither significant tilted displacements nor subsidence rates can extend inboard to distances, $x_{C}$, as far as $10^{3} \mathrm{~km}$ for any rigidity (Figures $9 \mathrm{a}$ and $9 \mathrm{~b}$ ). Plausible subsidence rates, but not displacements, can be found if $\Delta t$ is reduced to $1 \mathrm{~m} . \mathrm{y}$. (Figure 9c). However, this time interval is an order of magnitude smaller than the lower bound on the combined duration of Black River and Trenton deposition (Figure 2). If the convergence velocity is doubled to $V_{C}=10$ $\mathrm{cm} / \mathrm{yr}$, then tilted subsidence rates during Black River and Trenton deposition can be satisfied with a rigidity of $10^{27} \mathrm{Nm}$ (Figure $9 \mathrm{~d}$ ), but in this case $\Delta t$ must again be small (1 m.y.). Although not shown here, if $\Delta t=10 \mathrm{~m} . y$., increases in $V_{c}$ to more than $5 \mathrm{~cm} / \mathrm{yr}$ have no influence on displacements or subsidence rates because the trench is only just wider than 100 $\mathrm{km}$ and it takes only $2 \mathrm{~m} . \mathrm{y}$. for the margin to traverse this distance if the convergence toward the trench is $5 \mathrm{~cm} / \mathrm{yr}$. It must be emphasized that the displacement fields remain unchanged in these two latter cases when $\Delta t$ and $V_{c}$ are changed. Consequently, the Timor analogy model can be rejected for all sets of parameters, even for extreme plate rigidities.

\section{Dynamic Slab Model}

The dynamic slab models use an imposed buoyancy method in which a series of cases are computed assuming subduction of constant aged oceanic lithosphere [Gurnis, 1992]. The surface dynamic topography is determined for various slab lengths, slab dip angles, fault dip angles, and age of the subducted lithosphere as described above. The difference between these topographies approximates the subsidence or uplift associated with the lengthening of a slab or the change in slab dip as a function of time. The topography associated with a slab shows large amplitude, long-wavelength dynamic topographies on the overriding plate (Figure 6b). Short slabs are characterized by narrow (200 km wide) and deep (2-3 km deep without the loading of sediments) dynamic topographies. Shallow dipping and long slabs are associated with long-wavelength (> 1000 $\mathrm{km}$ scale) tilting [Gurnis, 1992]. Indeed, tilts extending up to $2000 \mathrm{~km}$ from the trench are possible for shallow slabs extending through the entire upper mantle. Presently, both continental and oceanic areas are depressed by up to $1 \mathrm{~km}$ over slabs [Gurnis, 1993].

The lengthening rate of a slab can be equated to the subduction velocity, and values from $2 \mathrm{~cm} / \mathrm{yr}$ to $10 \mathrm{~cm} / \mathrm{yr}$ are reasonable. For the present application to the Ordovician, the age of oceanic lithosphere thrusting under the continent would almost certainly have been old because of the large size of the Iapetus ocean [Van der Voo, 1993]. The effect of a lengthening slab which has a constant dip is shown in Figure 10. A slab with a $30^{\circ}$ dip, similar to the central Japan slab today, can easily give long-wavelength displacements of a few hundred meters at a distance of more than $10^{3} \mathrm{~km}$ from the trench (Figures 10 and $11 \mathrm{~b}$ ). The results for displacements and subsidence rate (Figures $11 \mathrm{a}$ and $11 \mathrm{~b}$ ) are created by differencing the dynamic topography from a case with a short slab $(250 \mathrm{~km}$, Figure 10) from that of a long slab $(550 \mathrm{~km}$, Figure 10 ). In this particular case, a $30^{\circ} \mathrm{dip}$, the modeled displacements do not adequately reproduce the Ordovician tilt in Michigan. If we increase only age of the subducted slab, from $80 \mathrm{Ma}$ to $140 \mathrm{Ma}$, the displacements are only shifted down by a constant factor (as shown by the dotted line for a $650-\mathrm{km}$-long slab; Figures 11a and 11b). By varying slab age
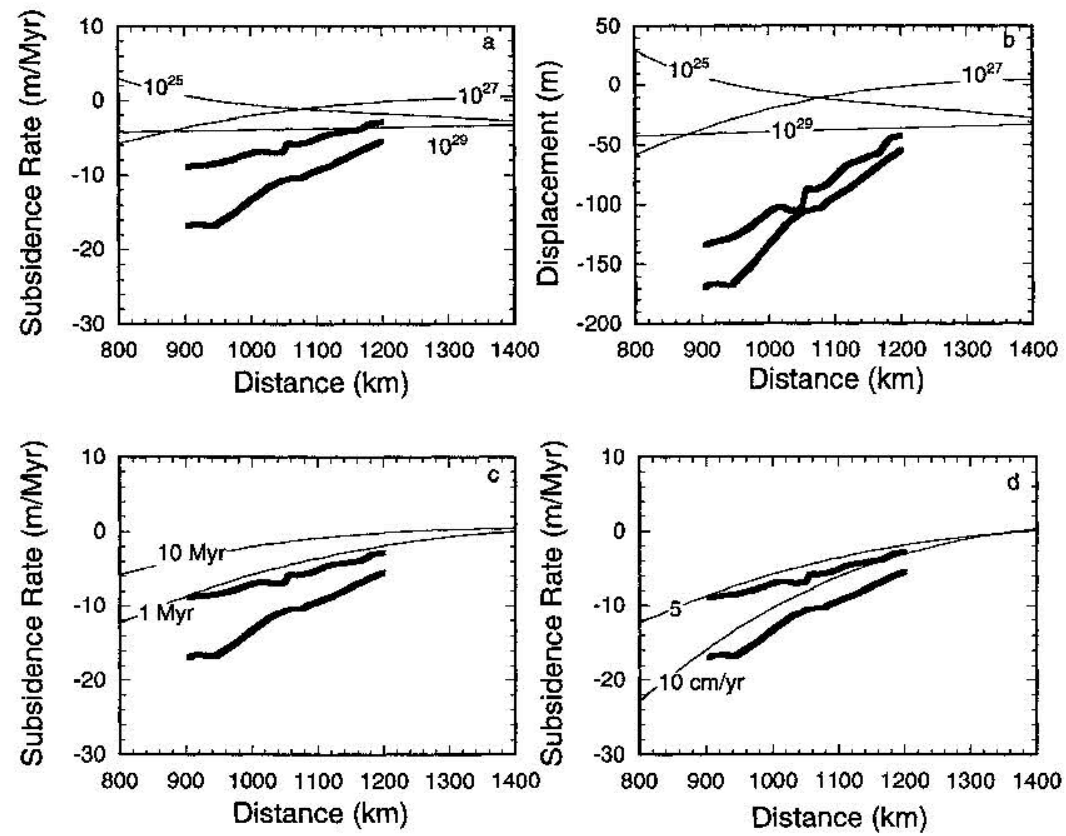

Figure 9. Results of attempted subduction of a continental margin into the modeled trench shown in Figure 7. (a) Subsidence rates and (b) displacements for the case where $\Delta t=10 \mathrm{~m}$.y. and $V_{c}=5 \mathrm{~cm} / \mathrm{yr}$ for three rigidities as labeled. (c) Effect of decreasing $\Delta t$ from 10 to $1 \mathrm{~m} . \mathrm{y}$. on subsidence rates and (d) effect of increasing $V_{C}$ from 5 to $10 \mathrm{~cm} / \mathrm{yr}$ (when $\Delta t=1 \mathrm{~m}$.y.) for plate rigidity of $10^{27} \mathrm{Nm}$ are shown. 


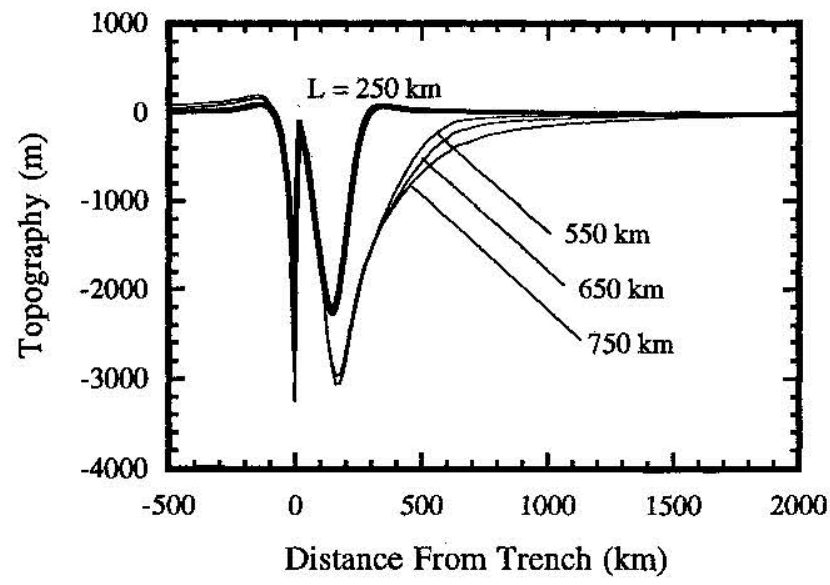

Figure 10. Dynamic topography over an $80 \mathrm{Ma}$ slab with a $30^{\circ}$ dip for four different slab lengths $(250 \mathrm{~km}$ shown by the thick line and $550 \mathrm{~km}, 650 \mathrm{~km}$, and $750 \mathrm{~km}$ shown by thin lines). The dynamic topography was computed assuming the surface is covered with water.

alone, we can not resolve this discrepancy between modeled and observed tilts. However, for $30^{\circ}$ dipping slabs, the subsidence rate can generally be satisfied as the slab increases in length from $250 \mathrm{~km}$ with a moderate rate of subduction (5 $\mathrm{cm} / \mathrm{yr}$ ). Since the initiation of subduction was probably in the early Caradocian, as much as 10 million years before the start of Black River deposition, it is likely that the slab was already a few hundred kilometers in length before the tilting of the Michigan Basin began. The subsidence profiles shown in
Figure 11a assume that the slab was $250 \mathrm{~km}$ and lengthens to $300 \mathrm{~km}$ in $6 \mathrm{~m} . \mathrm{y}$. and easily match the bounds on the Michigan tilted subsidence. If the slab becomes longer than $\sim 700 \mathrm{~km}$ at this dip, too much subsidence is predicted (Figure $11 \mathrm{~b})$.

Increased tilting, which better fits the observed displacements can be created by lengthening a slab with a shallower dip. The displacements can be fit when an older slab $\left(140 \mathrm{Ma}\right.$ in age) has a length of $500 \mathrm{~km}$ and a dip of $20^{\circ}$ (Figure 11d). However, as the slab increases in length even by a few hundred kilometers more, significantly larger model displacements than observed will be created. If the slab subducts at a slow velocity $(2 \mathrm{~cm} / \mathrm{yr}$, as suggested by McKerrow et al. [1990] then the tilted subsidence rates are also satisfied. If the velocity of convergence is significantly faster than $2 \mathrm{~cm} / \mathrm{yr}$, then the total displacement field remains the same but the subsidence rates become unacceptably larger than observed (dotted line, Figure $11 \mathrm{c}$ ). If the slab continues to lengthen, it not only gives rise to unreasonable displacements, but also unreasonable subsidence rates (for example, after $40 \mathrm{~m} . y$. the slab has lengthened to $1000 \mathrm{~km}$ ) and gives subsidence rates substantially larger than observed (Figure 11c). If the tilting is caused by a relatively shallow dipping slab, then it must bend over and descend at a much steeper dip to avoid unreasonable displacements (Figure 11d).

\section{Discussion}

The total tectonic subsidence and subsidence rates during deposition of the Black River and Trenton Formations strongly restrict the acceptable range of dynamic slab models.
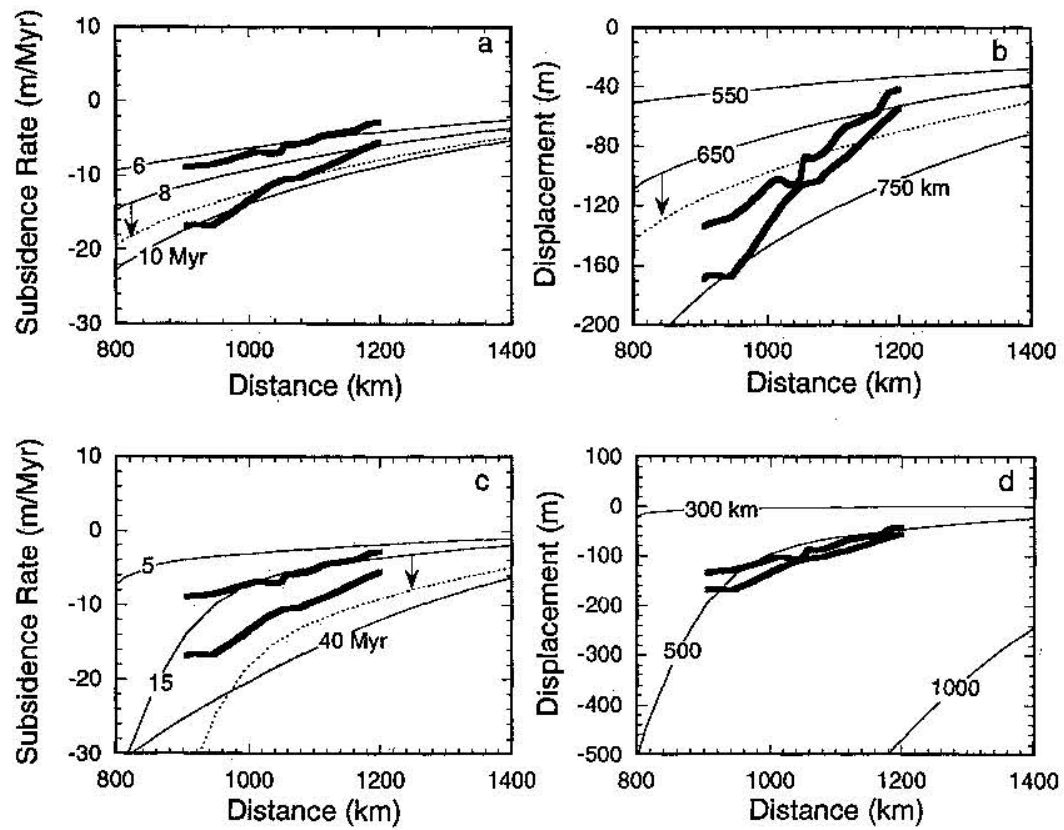

Figure 11. Results of increasing the length of a subducted slab under a continent. (a) Subsidence rate and (b) displacements for a $30^{\circ}$ dipping slab with an age of $80 \mathrm{Ma}$ subducting at $5 \mathrm{~cm} / \mathrm{yr}$ for a $550-\mathrm{km}$-long slab increasing in length from $250 \mathrm{~km}$ in $6 \mathrm{~m} . \mathrm{y}$, a $650 \mathrm{~km}$ slab in $8 \mathrm{~m} . \mathrm{y}$., and a $750-\mathrm{km}$ slab in $10 \mathrm{~m} . \mathrm{y}$. The effect of increasing the age of the $650-\mathrm{km}$-long slab from $80 \mathrm{Ma}$ to $140 \mathrm{Ma}$ is shown by the dotted line. For Figures $11 \mathrm{a}$ and $11 \mathrm{~b}$ the raw dynamic topography used to compute these results are shown in Figure 10. (c) Subsidence rate and (d) displacements for a $20^{\circ}$ dipping slab which lengthens to $300 \mathrm{~km}$ in $5 \mathrm{~m}$.y., $500 \mathrm{~km}$ in $15 \mathrm{~m} . \mathrm{y}$. and $1000 \mathrm{~km}$ in $40 \mathrm{~m} . \mathrm{y}$. In Figure $11 \mathrm{c}$ the effect of increasing the subduction rate from $2 \mathrm{~cm} / \mathrm{yr}$ to $5 \mathrm{~cm} / \mathrm{yr}$ is shown by the dotted line. 
Both models dependent on the rigidity of the lithosphere, simple supracrustal loading, and descent of the continental margin into a trench can be rejected. The simple supracrustal load model requires a combination of lithosphere rigidities 2 to 3 orders of magnitude larger than inferred today and loads which are unrealistically wide and thick. In the case of the descent of a continent into a trench, the displacement field cannot be satisfied for any set of parameters, although the subsidence rate can be satisfied if the time interval of deposition is $1 \mathrm{~m} . \mathrm{y}$,, which leads us to reject the model since it is at least 1 order of magnitude smaller than the time span observed for the combined Black River and Trenton formations.

The dynamic slab model, however, easily satisfies both displacement and subsidence rate, but only for a restricted range of slab dip angles and subduction rates. Slabs which are too long or have dip angles too shallow lead to excessive amounts of far-field displacement. We propose the following scenario which is summarized in Figure 12. Throughout the end of the Sauk sequence and up until about Whiterockian time ( $475 \mathrm{Ma})$ Laurentia was surrounded by an Atlantic-type passive margin (Figure 12a). Subduction initiated along the eastern margin of Laurentia during the period $470-460 \mathrm{Ma}$ (Figure 12b), the initiation may have proceeded northward as indicated by the diachronous subsidence of basins in Tennessee and Pennsylvania [Shanmugam and Lash, 1982]. We propose that the rapid subsidence, via the development of narrow block-faulted basins, evident in the Sevier basin of eastern Tennessee and the Martinsburg basin of eastern Pennsylvania, was caused by the initial thrusting under the former passive margin of a westward dipping slab attached to the Iapetus oceanic plate. This phase was not accompanied by volcanism. Earlier, Shanmugam and Lash [1982] hypothesized that these narrow basins formed when the eastern margin of Laurentia descended into a trench formed by a slab dipping eastward under the Iapetus plate, but the stratigraphy and structure appears to be equally consistent with the thrusting of a westward dipping slab under the margin. The tectonics may be analogous to the formation of the South Wanganui Basin on the southern part of the North Island of New Zealand which rapidly subsided in response to the initiation of subduction under that area [Stern et al., 1992]. This basin is directly over the slab, about $100 \mathrm{~km}$ wide, a few hundred kilometers from the trench, has a block faulted basement, and experienced subsidence rates of $-10^{3} \mathrm{~m} / \mathrm{m}$.y. during the Pleistocene. Benedict and Walker [1978] estimate that the middle Ordovician sediments above the Knox unconformity in eastern Tennessee indicate subsidence rates
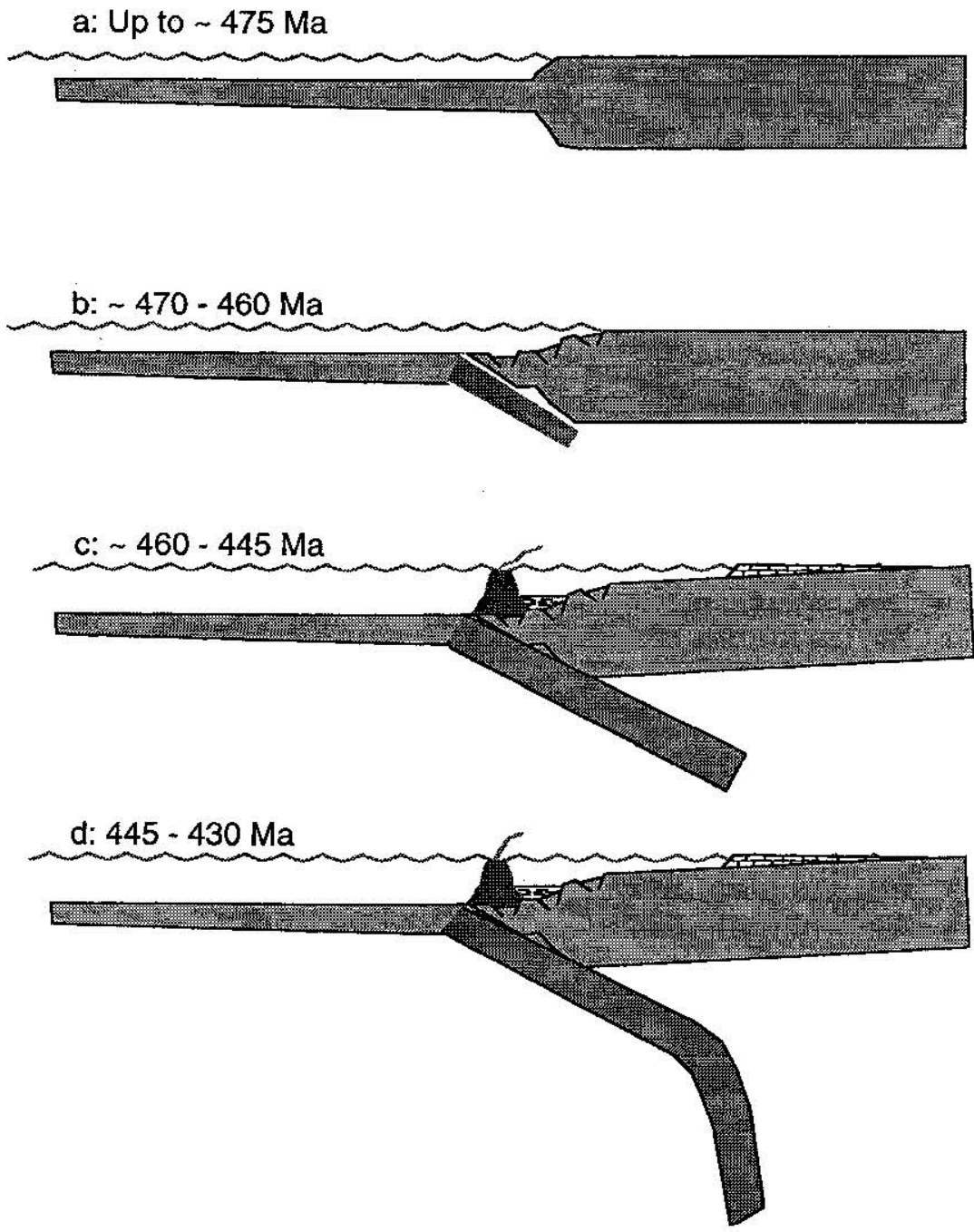

Figure 12. Schematic of the evolution of a slab following initiation of subduction off the east coast of Laurentia during the Ordovician. The details of the evolution are discussed in the text. 
which exceeded $400 \mathrm{~m} / \mathrm{m} . y$, albeit with a large uncertainty, quite consistent with the New Zealand, subduction-initiation analogy. The descent of Laurentia into a trench also cannot explain the far-field subsequent rapid tilting observed in the Michigan Basin sediments.

The Black River and Trenton Formations are separated by the Diecke and Milbrig Bentonites which are usually interpreted as the start of significant island arc or Andean-type volcanism off the east coast of Laurentia [Huff et al., 1992 ]. The appearance of volcanism, as indicated by the Bentonite layers, suggest the influence of a fully developed slab. As the slab was thrust further under the margin, Laurentia was tilted down toward the east (Figure 12c). As shown above, a shallow dipping (about $20^{\circ}$ ) slab is most compatible with the observations. A flat lying slab would not only give rise to vertical displacements which exceed observed tectonic subsidence but would also give rise to a Laramide type continental tectonics (e.g., as discussed for present-day South America by Barazangi and Isacks [1976]) through coupling of the flat slab to the overlying continental lithosphere. Compressional deformation beyond the Appalachian front has not been observed.

One problem with proposing that the Martinsburg basin in eastern Pennsylvania subsided in response to the same slab which caused the Michigan Basin to subside during Black Riverian to Maysvillian time is that the deposition of the Martinsburg Formation in eastern Pennsylvania overlaps in time with the deposition of the Black River. We would expect a 10-15 m.y. time delay between the two (Figure 12c). However, if the slab was coming from a somewhat more southerly direction, then there is not a time problem since the appearance of the Blockhouse formation in Tennessee occurs at a reasonable 10-15 m.y. before Black River subsidence. The orientation of the contours of constant subsidence rate in the Michigan Basin, however, suggest underthrusting from a more easterly source (e.g., eastern Pennsylvania).

Finally, we propose that after the slab lengthened by about $500 \mathrm{~km}$ at a moderately shallow $\operatorname{dip}\left(20^{\circ}\right)$, the slab descended near vertical and thus avoiding further far-field displacements (Figure 12d). The relatively thin carbonate layers which we suggest are indicative of slab dynamics, eventually became covered with thick Queenston wedge clastics as the Taconic orogeny reached its peak in the Late Ordovician and early Silurian. We further would suggest that the tilting events are better described as being pre-Taconic since the subsidence occurs before the generation of the Taconic orogenic belt.

This inference of far-field tilting generated by a slab has important implications for models for the initiation of subduction and for understanding the time-dependent dynamics of subducted slabs. At a passive margin which abuts old oceanic lithosphere, it is generally thought that it may be difficult for the buoyancy of the lithosphere to overcome its strength [e.g., Cloetingh, et al,, 1989]. In a recent review, Mueller and Phillips [1991] assumed the traditional scenario of an eastward dipping slab underthrusting Iapetus and ruled out the bypothesis that initiation occurs by the failure at an Atlantic-type passive margin by the weight of cold, old oceanic lithosphere. However, an implication of this work is that initiation of subduction could be due to the failure of old oceanic lithosphere at a passive margin followed by the motion of a slab under the continental margin and interior. A reassessment of the failure of old passive margins needs to be readdressed.
Models of the mantle and lithosphere now incorporate fully dynamic plates with plate margins simulated with faults, and with realistic temperature-, pressure-, and stress-dependent rheologies, and phase transitions and these models show fundamental time-dependent changes in the dip of slabs as they thrust under continents [Zhong and Gurnis, 1995]. Changes in dip angle are associated with trench rollback and variations in the velocity of subducting plates. The observational inferences made in this paper, that a slab first dips at a shallow angle before descending near vertically, will ultimately allow us to constrain these time-dependent dynamic models of mantle flow.

\section{Conclusions}

In examining the subsidence history of the Michigan Basin in map view we are confronted with the unexpected tilting of the basin toward the east during the middle Ordovician. This event was laterally extensive, as indicated by isolated outliers of similar aged sediment on the Canadian shield [Cook and Bally, 1975] and unique in time, the Black River Formation overlies the Precambrian basement at the limit of Paleozoic deposition in southern Ontario [Freeman, 1979].

We find that traditional models of supracrustal loading on an elastic lithosphere are inadequate to reproduce the observed regional deformation, requiring the subcrustal loading model proposed here. This model is compatible with the subduction vergence proposed by McKerrow et al. [1991] and provides a means to view the Michigan Basin in its regional context, as influenced by constrainable external tectonic events. It is unclear how the stratigraphic expression of this event was influenced by the peculiarities of the underlying lithosphere, leading to permanent subsidence in the Michigan Basin and isolated outliers of carbonate sediments on the Canadian shield. It is clear that viewing the vertical motions of the continent in the regional tectonic context provided by the plate tectonic history of adjacent areas will help expand our understanding of sedimentary basins beyond simple, empirical relationships.

Acknowledgments. B.J.C. was supported by a grant from the Gas Research Institute under contract 5089-260-1810. M.G. is supported by a fellowship from the David and Lucile Packard Foundation and by NSF grant EAR 9496185. Thanks to Greg Nadon, Herb Wang, Jeff Nunn, and Paul Howell for enlightening, continuing discussions. We thank Shijie Zhong for assistance with the finite element modeling. Contribution number 5394, Division of Geological and Planetary Sciences at Caltech.

\section{References}

Ahern, J. L., and P. J. Dikeou, Evolution of the lithosphere beneath the Michigan Basin, Earth Planet. Sci. Lett., 95, 73-84, 1989.

Barazangi, M., and B. L. Isacks, Spatial distribution of earthquakes and subduction of the Nazca plate beneath South America, Geology, 4, 686-692, 1976.

Benedict, G. L., and K. R. Walker, Paleobathymetric analysis of Paleozoic sequences and its geodynamic significance, Am. J. Sci., 278, 579-607, 1978.

Bird, J. M., and J. F. Dewey, Lithosphere plate-continental margin tectonics and the evolution of the Appalachian orogen, Geol. Soc. Am. Bull., 81, 1031-1059, 1970.

Bond, G. C., and M. A. Kominz, Disentangling Middle Paleozoic sea level and tectonic events in cratonic margins and cratonic basins of North America, J. Geophys. Res., 96, 6619-6639, 1991. 
Bradley, D. C., and T. M. Kusky, Geological evidence for rate of plate convergence during the Taconic arc-continent collision, J. Geol., 94, 667-681, 1986.

Catacosinos, P. A., W. B. Harrison III, and P. A. Daniels Jr., Structure, stratigraphy and petroleum geology of the Michigan Basin, in Interior Cratonic Basins, edited by M. W. Leighton, D. R. Kolata, D. F. Oltz, and J. J. Eidel, pp. 561-601, American Association of Petroleum Geologists, Tulsa, Okla., 1990.

Cloetingh, S., R. Wortel, and N. J. Vlaar, On the initiation of subduction zones, Pure Appl. Geophys., 129, 7-25, 1989.

Cloetingh, S. A. P. F., H. McQueen, and K. Lambeck, On a tectonic mechanism for regional sea level variation, Earth Planet. Sci. Lett., 75, 157-166, 1985 .

Cloetingh, S. A. P. F., F. M. Gradstein, H. Kooi, A. C. Grant, and M. Kaminski, Plate reorganization: A cause of rapid late Neogene subsidence and sedimentation around the North Atlantic, J. Geol. Soc. London, 147, 495-506, 1990.

Coakley, B. J., G. Nadon, and H. F. Wang, Spatial variations in tectonic subsidence during Tippecanoe I in the Michigan Basin, Basin Res., 6, 131-140, 1994.

Cohee, G. V., Cambrian and Ordovician rocks in the Michigan Basin and adjoining areas., Am. Assoc. Pet. Geol. Bull., 32, 1417-1448, 1948.

Cook, T. D., and A. W. Bally, Stratigraphic Atlas of North and Central America, 272 pp., Princeton University Press, Princeton, N. J., 1975.

Freeman, E. B., Geological Highway Map, southern Ontario, 1:800,000, Ontario Geological Survey, Map \#2418, 42N to 46N and 72W to 84W, 1978.

Gallagher, K., T. A. Dumitru, and A. J. W. Gleadow, Constraints on the vertical motion of eastern Australia during the Mesozoic, Basin Res., 6, 77-94, 1994.

Grotzinger, J. P., and L. Royden, Elastic strength of the Slave Craton at 1.9 Gyr and implications for thermal evolution of the continents, Nature, 347, 64-66, 1990.

Gurnis, M., Rapid continental subsidence following the initiation and evolution of subduction, Science, 255, 1556-1558, 1992.

Gurnis, M., Depressed continental hypsometry behind oceanic trenches: A clue to subduction controls on sea-level change, Geology, 21, 29$32,1993$.

Hamdani, Y., J. C. Mareschal, and J. Arkani-Hamed, Phase changes and thermal subsidence in intracontinental sedimentary basins, Geophys. J. Int. 106, 657-665, 1991.

Harland, W. B., R. L. Armstrong, A. V. Cox, L. E. Craig, A. G. Smith, and D. G. Smith, A Geologic Time Scale 1989, 263 pp., Cambridge University Press, New York, 1990.

Hetenyi, M., Beams on Elastic Foundations, 255 pp., University of Michigan Press, Ann Arbor, 1947.

Howell, P. D., and B. A. van der Pluijm, Early history of the Michigan Basin: Subsidence and Appalachian tectonics, Geology, 18, 1195$1198,1990$.

Huff, W. D., S. M. Bergstrom, and D. R. Kolata, Gigantic Ordovician volcanic ash fall in North America and Europe: Biological, tectonomagmatic and event-stratigraphic significance, Geology, 20, 875-878, 1992.

Jacobi, R. D., Peripheral bulge-A causal mechanism for the Lower/Middle Ordovician unconformity along the western margin of the Northern Appalachians, Earth Planet. Sci. Lett. 56, 245-251, 1981.

Janssen, M. E., M. Torne, S. Cloetingh, and E. Banda, Pliocene uplift of the eastern Iberian margin: Inferences from quantitative modelling of the Valencia trough, Earth Planet. Sci. Lett., 119, 585-597, 1993.

Jordan, T. E., Thrust loads and basin evolution, Cretaceous, western United States, Am. Assoc. Pet. Geol. Bull. 65, 2506-2520, 1981.

Karner, G. D., Effects of lithospheric in-plane stress on sedimentary basin stratigraphy, Tectonics, 5, 573-588, 1986.

Karner, G. D., M. S. Steckler, and J. A. Thorne, Long-term thermomechanical properties of the continental lithosphere, Nature, 304, 250-253, 1983.

Keith, B. D., Regional facies of upper Ordovician series of eastern
North America, in The Trenton Group (Upper Ordovician Series) of Eastern North America, edited by B. D. Keith, pp. 1-16, American Association of Petroleum Geologists, Tulsa, Okla.,1989.

Knight, I., N. P. James, and T. E. Lane, The Ordovician St. George Unconformity, northern Appalachians: The relationship of plate convergence at the St. Lawrence Promontory to the Sauk/Tippecanoe sequence boundary, Geol. Soc. Am. Bull., 103, 1200-1225, 1991.

McKenzie, D., Some remarks on the development of sedimentary basins, Earth Planet. Sci. Lett., 40, 25-32, 1978.

McKerrow, W. S., The development of the Iapetus Ocean from Arenig to Wenlock, in The Caledonian-Appalachian Orogen, edited by A. L. Harris and D. J. Fettes, pp. 405-412, Geological Society of London, 1988.

McKerrow, W. S., J. F. Dewey, and C. R. Scotese, The Ordovician and Silurian development of the Iapetus Ocean, Spec. Pap. Paleontol., 44, 165-178, 1991.

Mitrovica, J. X., C. Beaumont, and G. T. Jarvis, Tilting of continental interiors by the dynamical effects of subduction, Tectonics, 8,1079 1094, 1989.

Mueller, S., and R. J. Phillips, On the initiation of subduction, $J$. Geophys. Res., 96, 651-665, 1991.

Mussman; W. J., and J. F. Read, Sedimentology and development of a passive- to convergent-margin unconformity: Middle Ordovician Knox unconformity, Virginia Appalachians, Geol. Soc. Am. Bull, 97, 282-295, 1986.

Nadon, G. C., and G. L. Smith, Extending unconformities into basin centers: An example from the Early to Middle Ordovician of the central Michigan Basin, in Paleokarst, Karst-Related, Diagenesis and Reservoir Diagenesis: Examples From Ordovician-Devonian Age Strata from West Texas and the Mid-Continent, edited by $\mathrm{M}$. Candeleria and C. Reed, pp. 153-164, Permian Basin Section, Society of Economic Paleontologists and Mineralogists, Tulsa, Okla. 1992.

Nunn, J. A., Subsidence and thermal history of the Michigan Basin, in Thermal Modeling in Sedimentary Basins, edited by J. Burrus, pp. 417-436, Editions Technip, Paris, 1986.

Nunn, J. A., Free thermal convection beneath intracratonic basins: Thermal and subsidence effects, Basin Res., 6, 115-130, 1994.

Parsons, B., and J. G. Sclater, An analysis of the variation of ocean floor bathymetry and heat flow with age, J. Geophys. Res., 82, 803-827, 1977.

Peper, T., Tectonic and eustatic control on Albian shallowing (Viking and Paddy Formations) in the Western Canada Foreland basin, Geol. Soc. Am. Bull., 106, 253-264, 1994.

Quinlan, G. M., and C. Beaumont, Appalachian thrusting, lithospheric flexure, and the Paleozoic stratigraphy of the Eastern Interior of North America, Can. J. Earth Sci., 21, 973-996, 1984.

Richards, M. A. and B. H. Hager, Geoid anomalies in a dynamic Earth, J. Geophys. Res., 89, 5987-6002, 1984.

Rodgers, J., The Taconic Orogeny, Geol. Soc. Am. Bull., 82, 1141$1178,1971$.

Russell, M., and M. Gurnis, The planform of epeirogeny: Vertical motions of Australia during the Cretaceous, Basin Res., 6, 63-76, 1994.

Samson, S. D., P. J. Patchett, J. C. Roddick, and R. R. Parrish, Origin and tectonic setting of Ordovician bentonites in North America: Isotopic and age constraints, Geol. Soc. Am. Bull., 101, 1175-1181, 1989.

Sclater, J. G., and P. A. F. Christie, Lithospheric stretching in the North Sea, J. Geophys. Res., 85, 12,873-12,990, 1980.

Scotese, C. R. and W. S. McKerrow, Ordovician plate tectonic reconstructions, in Advances in Ordovician Geology, edited by C. R. Barnes and S. H. Williams, pp. 271-282, Geological Survey of Canada, Ottawa, Ontario, 1991.

Shanmugam, G., and G. G. Lash, Analogous tectonic evolution of the Ordovician foredeeps, southern and central Appalachians, Geology, 10, 562-566, 1982.

Shanmugam, G., and K. R. Walker, Tectonic significance of distal turbidites in the Middle Ordovician Blockhouse and Lower Sevier Formations in East Tennessee, Am. J. Sci., 278, 551-578, 1978. 
Sleep, N. H. and N. S. Snell, Thermal contraction and flexure of MidContinent and Atlantic marginal basins, Geophys. J. R. Astron. Soc., 45, 125-154, 1976.

Sleep, N. H., J. A. Nunn, and L. Chou, Platform Basins, Annu. Rev. Earth Planet. Sci., 8, 17-34, 1980.

Sloss, L. L., Sequences in the cratonic interior of North America, Geol. Soc. Am. Bull., 74, 93-114, 1963.

Steckler, M. and A. B. Watts, Subsidence of the Atlantic-type continental margin off New York, Earth Planet. Sci. Lett., 41, 1-13, 1978.

Stern, T. A., G. M. Quinlan, and W. E. Holt, Basin formation behind an active subduction zone: Three-dimensional flexural modeling of the Wanganui Basin, New Zealand, Basin Res., 4, 197-214, 1992.

Sweet, W. C., Graphic correlation of upper Middle and Upper Ordovician rocks, North American Midcontinent Province, U.S.A., in Aspects of the Ordovician System, edited by D. L. Bruton, pp. 23-35, Universitetsforlaget, Oslo, 1984.

Sweet, W. C., Mohawkian and Cincinnatian chronostratigraphy, $N . Y$. State Mus. Bull., 462, 84-90, 1988.

Thorne, J., and A. B. Watts, Seismic reflectors and unconformities at passive continental margins, Nature, 311, 365-386, 1984.

Tucker, R. D., T. E. Krogh, R. J. J. Ross, and S. H. Williams, Time-scale calibration by high-precision U-Pb zircon dating of interstratified volcanic ashes in the Ordovician and Lower Silurian stratotypes of Britian, Earth Planet. Sci. Lett., 100, 51-58, 1990.
Van der Voo, R., Paleomagnetism of the Atlantic, Tethys and the Iapetus Oceans, 411 pp., Cambridge University Press, New York, 1993.

Walker, K. R., G. Shanmugam, and S. C. Ruppel, A model for carbonate to terrigenous clastic sequences, Geol. Soc. Am. Bull., 94, 700-712, 1983.

Watts, A. B., Tectonic subsidence, flexure and global changes of sea level, Nature, 297, 469-474, 1982.

Zhong, S., and M. Gurnis, Viscous flow model of a subduction zone with a faulted lithosphere: Long and short wavelength topography, gravity and geoid, Geophys. Res. Lett., 19, 1891-1894, 1992.

Zhong, S., and M. Gurnis, Controls on trench topography from dynamic models of subducted slabs, J. Geophys. Res., 99, 15,683-15,695, 1994.

Zhong, S., and M. Gurnis, Mantle convection with plates and mobile, faulted plate margins, Science, in press, 1995.

B. Coakley, Lamont-Doherty Earth Observatory, 107 Oceanography, Palisades, NY 10964 (e-mail: bjc@ldeo.columbia.edu)

M. Gurnis, Seismological Laboratory 252-21, California Institute of Technology, Pasadena, CA 91125 (e-mail: gurnis@caltech.edu)

(Received March 24, 1994; revised October 26, 1994; accepted November 2, 1994) 